DOI https://doi.org/10.15407/usim.2019.04.027

UDC 004.4451

M.V. IVASHCHENKo, Student of the Faculty of Applied Mathematics,

National Technical University of Ukraine "Igor Sikorsky Kyiv PolitechnicI nstitute",

03056, Peremohy Ave, 37, Kyiv, Ukraine,

mivaschenko_51@lll.kpi.ua

D.D. OKHRYMCHUK, Student of the Faculty of Applied Mathematics,

National Technical University of Ukraine "Igor Sikorsky Kyiv PolitechnicI nstitute",

03056, Peremohy Ave, 37, Kyiv, Ukraine,

den5096@gmail.com

L.A. LYUSHENKO, PhD (Eng.), Senior Lecturer,

National Technical University of Ukraine "Igor Sikorsky Kyiv Politechnic Institute",

03056, Peremohy Ave, 37, Kyiv, Ukraine,

lyushenkol@gmail.com

\title{
INTEGER NORM FOR DIFFERENCE ASSESSMENT OF THE FRAME ELEMENTS CONSIDERING THE WHITE BALANCE
}

The proposed concept suggests a method, based on which a synthesis of an integer norm can be performed, which takes into account the white balance of the camera when performing the evaluation of the difference between the elements of an image. This idea is based on modifying the internal calculations of the camera, aimed at assessing the colour of the element of the image, using the process of colour model reduction that is embedded inside the camera, to the colour model of the classical representation. The use of this approach provides a number of advantages within the framework of systems in which there is a solution of computer vision problems in terms of using both graphical processing and artificial intelligence.

Keywords: computer vision, white balance correction, colour sensors, colour model, reference colours, image point norm.

\section{Introduction}

Human organism possesses the ability to see, determine and understand the environment using the visual information. The same idea was also formed and implemented in the computer vision technologies. Such technologies are usually used in surveillance systems, robotics, tracking mobile applications, engineering reliability and quality control etc. In every computer vision system, it is needed to track how the image has changed (or how the points of the image have changed).

Computer vision systemsbuilt over modern CCD CMOS-sensors, allow adjust automatically the parameters of a frame according to the surrounding illumination, its position changesin space, integral characteristics of the frame, and other parameters that can indirectly influence the raster quality.

The increase of the computational power in digital signal processorsbuilt in the sensor systems of computer vision allows on the one hand to significantly improve consumer and metrological characteristics of the finished device without tightening the technological requirements, but on the other hand requires specific processing algorithms that are attached to the architecture and scheme parameters of the specific device.

In this paper are presented the results of the research based on the task of forming the difference assessment between two elements of a raster frame, that allows the conversion of the incoming data 
and the results of the comparison on hypothetically arbitrary bit grids distributed to a set of individual raster points representation ways, including colour schemes and device configuration parameters.

Nowadays computer vision is developing in a wide variety of fields, one of which is machine learning, specifically deep learning that manages the high-level data composed into the hierarchical structures. It improves the abilities of chipprogramming using relatively cheap computational equipment [1].

A distinctive feature of computer vision engineering and technology is the usage of adaptive algorithms and learning systems that are the basis for the practical computer vision usage in any valuable automation tasks.

It leads to active implementation and development of the deep learning algorithms, weak artificial intelligence in terms of configuration and learning process, artificial intelligence for the recognition and classification tasks. The mentioned techniques that are used for solving the issues of signals digital processing in machine vision allow the active usage of phase-frequency and adaptive filtering, spectral analysis methods, wavelet transformation in the early stages of reading information from the matrix photo detectors on the programming and hardware levels. It also allows to reduce significantly the computational costs of image processing algorithms and distribute the processing between all links of machine vision chains.

Nevertheless, all the tasks described above are reduced to the basic task of computer vision, namely: comparison of image points or series of images. This process is implemented in terms of work with the colour models. Each colour model defines the way of a point's colour representation and the way of its encoding inside a device.

The difference assessment between two elements of a frame is a very important block of all image processing algorithms. However, nowadays the most of the norms that are defined over the colour spaces, perform the operations with the float values. When implementing algorithms for calculating the norm into the hardware logic of sensors, the usage of float arithmetic is unacceptable as it significantly increases the computational costs and also the hardware requirements of the sensors causing a great reduce in the performance level of the norm computational algorithms in terms of impossibility of their paralleling.

Thus, the development of integer norms over the colour spaces will allow to organize an efficient ima-ge processing using the means of a device.

In this article RGB colour model is reviewed. This model applies the additive method of colour processing (a colour is obtained by adding to black). It is known that any colour can be represented as a combination of three colours: red (R), white (W), and blue (B). These colours are also known as the reference colours and are specified by values from 0 to 255 . RGB colour model allows the usage of ima-ge points colour identification of implementing the three-channel colour representation. It allows to perform the image normalization process exclu-ding the set of operations that are specific for and are defined over the float arithmetic.

Let us review the described approach.

\section{Problem Description}

Let there be a raster rectangular image of the resolution $W \times H \times C$, where $W$ is the number of pixels in the width of the image, $H-$ the number of pixels in the height of the image, $C-$ the colour depth of the image (the number of bits used for contacting the representation of a colour in terms of a pixel encoding process). The position of every point of the image is uniquely determined by a pair of coordinates $(X ; Y)$, where $X=\overline{1 . . W}, Y=\overline{1 . . H}$. In this case the content of every point is represented by a colour that is encoded by the device.

Let there be a point of animage that is determined by a pair $\left(X_{1} ; Y_{1}\right)$, where $X_{1}=\overline{1 . . W}, Y_{1}=\overline{1 . . H}$. It is needed to build an assessment, how this point differs from another point of the same image with a pair of coordinates $\left(X_{2} ; Y_{2}\right)$, where $X_{2}=\overline{1 . . W}, Y_{2}=\overline{1 . . H}$. This task can be solved by finding the distance between the points on the colour surface.

The content of a point of an image can be given as a linear combination of a colour model reference points that is assigned by a polygon on the colour surface. Thus, in general the difference between the two colors is to be defined according to the distance 
between the colours. This distance can be computed as the length of a segment which endpoints are the positions of the colours on the surface.

Let us review the situation where each of the devices makes certain adjustments to the immediate appearance of the colour model when performing white balance correction by deforming it. As a result, both the appearance of the polygon that limits the area of the colour plane and determines the internal colour scheme of the device, and the appearance of the surface that describes the colour gamut can change. While image processing algorithms take into account only some standards [2] or use classical representations of colour schemes, matching them with the results obtained from the camera, it makes sense to perform the final distance calculations considering the changes of the colour model due to the camera's white balance corrections before obtaining every next frame. As a result, the colour channel component values will be converted according to the white balance factors calculated after shooting the scene, and subsequently represented in traditional RGB color model.

Then the final task of finding the difference between the two points of an image can be decreased to the following actions:

- performing the reduction of colour values obtained from the device to the values of the original color model;

- computing the distance between the points by calculating the norm (the problem can be set as a synthesis of a different type of a norm in terms of working with integer values and consideration of the white balance corrections).

Speaking of the problem of the device colour scheme structure, the solution is to use the reference colours system conversion and the resulting change in the appearance of the colour surface, as well as the color gamut. This step can be performed as a precomputed set of operations.

\section{Related Works. Colour Conversion}

The process of manufacturing, testing and automated adjustment of sensors involves the rejection and calibration of individual light-sensitive elements. The result of reading the image with some accuracy provides a representation of colours in a vector form, taking into account the calibrating parameters.

Let us review the models of obtaining the image element data according to the results of measurements in individual photosensors.

\section{Matrix Method}

This method is used if the assessment of several colours is needed. The method is based on the matrix equation: the values $(X ; Y ; Z)$ represent the colours in the source colour model, the values $(R ; G ; B)$ are the representation of the digital data of the colour sensor. The conversion matrix $\mathrm{C}$ is based on the output signals of the reference colour obtained during the calibration process. After the matrix coefficients are defined the values $(X ; Y ; Z)$ can be computed from the conversion of the $(R ; G ; B)$ sensor values.

$$
\left(\begin{array}{l}
X \\
Y \\
Z
\end{array}\right)=\left(\begin{array}{lll}
C_{11} & C_{12} & C_{13} \\
C_{21} & C_{22} & C_{23} \\
C_{31} & C_{32} & C_{33}
\end{array}\right) \cdot\left(\begin{array}{l}
R \\
G \\
B
\end{array}\right)
$$

\section{Table Method}

This method is used if it is needed to define several colours simultaneously. The first step is to determine how important the brightness is. For each colour the sensor uses brightness information that was obtained during calibration from the reference colours set. If the brightness information is not important, then a specifically selected colour channel is used for the search of the ratios between the reference colors obtained during calibration and the determined colour (taken as the basis for all measurement sets).

The brightness matters:

$$
\sqrt{\left(R_{1}-R_{0}\right)^{2} \cdot\left(G_{1}-G_{0}\right)^{2} \cdot\left(B_{1}-B_{0}\right)^{2}} \text {. }
$$

The bright ness does not matter:

$$
\sqrt{\left(\begin{array}{c}
R_{u} \\
G_{u}
\end{array}-\frac{R_{r}}{G_{r}}\right)^{2}-\left(\frac{B_{u}}{G_{u}}-\frac{B_{r}}{G_{r}}\right)^{2}},
$$

where $\left(R_{1}, G_{1}, B_{1}\right)$ are the coordinates values of the investigated colour, $\left(R_{0}, G_{0}, B_{0}\right)-$ the coordinates values of the reference colour.

The colours formed by the above methods lead to an incorrect result in terms of light conditions, 
the sensor temperature and the sampling frequency changes. Attempting to adjust the calibration data contributes to the accumulation of errors and processing algorithms complication [3].

\section{Related Works. White Balance Correction Algorithms}

There are different approaches of white balance correction during the shooting of a scene (or scenes) using a device. The following section describes the basic versions of such algorithms.

\section{Gray World Theory}

This method provides automatic white balance correction by calculating the values $\left(R_{a v g} ; G_{a v g} ; B_{a v g}\right)$, such as $R_{\text {avg }}=G_{\text {avg }}=B_{\text {avg }}$, and is based on the fact that any scene can be converted into the gray channel. The coefficients are used for colour correction of the image points are obtained from the calculations of the ratios between the $\left(R_{\text {avg }} ; G_{\text {avg }} ; B_{\text {avg }}\right)$ values and the average value of the green channel.

$$
\begin{aligned}
R_{\text {avg }}=G_{\text {avg }}= & B_{\text {avg }}, \operatorname{corr} R=G_{\max } / R_{\max }, \operatorname{corr} B= \\
& =G_{\max } / B_{\max }, \operatorname{corr} G=1 .
\end{aligned}
$$

\section{Retinex Theory}

Another possible method was produced by Edwin Land [4].This method is based on the principle that the white colour is a combination of three maximum values of the colour channels as it transmits the maximum possible level of signals into every channel. This method forms the white colour according to the component values of the brightest point of the image. At the same time, white balance correction factors can be obtained in two different ways: $\operatorname{corr} R=G_{\max } / R_{\max }, \operatorname{corr} B=G_{\max } B_{\max }, \operatorname{corr} G=1$,

$$
\text { corr } R=R / R_{\max }, \operatorname{corr} B=B / B_{\max } \text {, }
$$$$
\operatorname{corr} G=G / G_{\max } .
$$

\section{Standard Deviation-Weighted Gray World}

Standard Deviation-Weighted Gray World method extends the representation of the Gray world method and was suggested by Lam [5].The image is divided into a certain number of blocks. For each block the standard deviations and values $\left(\mu_{R} ; \mu_{G} ; \mu_{B}\right)$ are calculated that correspond to the colour channels $R, G, B$. The value for each channel is computed using the weight coefficients for every block. For the $k$-th block an average deviation of the green channel can be evaluated using the formula:

$$
\text { Std Avg } G=\sum_{k=1}^{p} \frac{\sigma_{G}(k)}{\sum_{i=1}^{p} \sigma_{G}(i)} \cdot \mu_{G}(k) .
$$

Based on the obtained values the correction factors for each colour channel are evaluated:

$$
\begin{aligned}
& \operatorname{corr} G=\frac{S t d A v g R+S t d A v g G+S t v A v g B}{3 \cdot S t d A v g G}, \\
& \operatorname{corr} R=\frac{S t d A v g R+S t d A v g G+S t v A v g B}{3 \cdot S t d A v g R}, \\
& \operatorname{corr} B=\frac{S t d A v g R+S t d A v g G+S t v A v g B}{3 \cdot S t d A v g B} .
\end{aligned}
$$

\section{White Patches in YCbCr Colour Space}

This method was introduced by Wang, Chen and Fuh [6]. The image is represented in the $\mathrm{YCbCr}$ colour space. White balance correction factors can be obtained from the following expressions:

$$
\operatorname{corr} R=\frac{Y_{\max }}{R_{\text {avg }}}, \operatorname{corr} G=\frac{Y_{\max }}{G_{\text {avg }}}, \operatorname{corr} B=\frac{Y_{\max }}{B_{\text {avg }}},
$$

where $Y_{\max }-$ maximum intensity value in a given colour space [7].

\section{White Balance Automated Correction Process}

In the process of shooting, the device (a camera) is able to change the way of white balance correction (this effect is achieved through a number of modes built in to the algorithms of the camera).

The main advantage of this approach is its simplicity of implementation, as well as optimality in terms of the device usage. However, when shooting in RAW format, or solving computer vision issues aimed at searching the changes in the state of the image, and performing several images or several points of a specific image comparison in standard custom formats, such white balance correction implementation does not work properly (the white balance correction factors do not tend to unity).

As a part of the image points representation comparison, such white balance adjustments can affect the loss of a certain number of colours, leading to failures in the accuracy of colour components calculations which leads to an incorrect com- 
parison result. As a result, the computation of the distance between the representations of points on the colour surface that is performed by the means of the normalization process will return incorrect values, since the camera's white balance correction for the selected scene (selected image) was not taken into account.

\section{Proposed Approach}

Let us review the process of assessing the difference between two points of the image working in terms of the issue described in paragraph 2 of this paper. The camera automatically adjusts the white balance in accordance with one of the modes set in the camera by default. The assessment of the difference between two points of the image is performed by normalization. The Euclidean norm is used as the calculation method.

The incoming data for the calculation of the norm is represented by the colour values of the points obtained from the camera. At the same time, the obtained values are converted from the colour space of the camera to the traditional colour space by considering the white balance correction factors that were used during the image capture. This conversion allows to transform a polygon that is the colour representation of the camera on the surface into a polygon that is representation of the classical RGB model.

This conversion uses the matrix method and has the following structure:

$$
\left(\begin{array}{lllll}
C_{11} & C_{12} & C_{13} & \cdots & C_{1 m} \\
C_{21} & C_{22} & C_{23} & \cdots & C_{2 m} \\
C_{31} & C_{32} & C_{33} & \cdots & C_{3 m}
\end{array}\right) \cdot\left(\begin{array}{c}
x_{1} \\
x_{2} \\
x_{3} \\
\vdots \\
x_{m}
\end{array}\right)=\left(\begin{array}{c}
y_{1} \\
y_{2} \\
y_{3}
\end{array}\right),
$$

where matrix $C$ is the matrix of conversion, that considers the white balance correction in terms of transition to the colour model RGB traditional look, vector $\mathrm{X}$ - point representation in the camera color space, vector $\mathrm{y}$ - the resulting representation of a point in the RGB color space.

The calculations are performed in terms of working with integer values, and also can be used for direct implementation into the hardware logic of devices. This fact makes it possible to reduce both the overall cost of resources for the performing operations, as compared to the existing float arithmetic, and the requirements for the sensor configuration, thereby increasing the overall level of performance.

Thus, we obtain a complex normalization algorithm that takes into account white balance correction factors, and can be used both in the devices that perform the shooting and in computers for the organization of computer vision systems.

\section{Conclusion}

In the absence of the possibility to calibrate sensors directly during the use of the device, existing methods of colour identification are not as efficient as possible in terms of working with the computer vision issues. This is due to the fact that each of the devices (or rather, each of the sensors of this device) "receives" the corresponding section of the colour model, which is deformed relative to the similar standardized section allocated to the RGB model. In addition, in the process of shooting the device performs white balance adjustment based on the parameters set for it by default (as a set of automatic correction modes). On the basis of such parameters as the scene illumination, the position of the shot object, the position of the device relative to the scene, - for each of the frames its own correction is formed which entails another deformation of the section of the colour surface corresponding to the sensors of the device. As a result, the accuracy of image point color representation assessment analysis drops significantly, making it impossible to apply standard methods of computing the differences between two pixels by performing normalization since the actual positions of their representations on the colour surface differ from the positions of the representations identified by the device. These facts are also supported by the situation where the implementation of the float arithmetic in the algorithms for calculating the norm in the hardware logic of sensors, is unacceptable since it significantly increases the overall costs not only for the norm computation, but also increases the level of requirements for the sensor 
equipment, causing a significant drop in performance of normalizing algorithms due to the impossibility of their parallelization.

The approach proposed in the article, aims to eliminate these drawbacks. Colours comparison in terms of using a standardized colour model (gamut) allows not only to obtain the same results regardless of the applied device, but also makes it possible to form a comparative analysis of the devices. This effect is achieved by the means of the data conversion that is obtained from the camera after performing automatic white balance correction to the traditional colour model. This allows to increase the accuracy of measurements in solving computer vision issues aimed at comparing points of one image or at a full comparison of two or a series of images.

The algorithm can be wielded both in devices that shoot, and in computers that are used to perform image processing operations in computer vision systems.

\section{REFERENCES}

1. Sinha, R.K., Pandey, R., Pattnaik, R., 2017. “Deep Learning for Computer Vision Tasks: A review”. Int. Conf. on Intelligent Computing and Control (I2C2), pp. 1-5, https://arxiv.org/ftp/arxiv/papers/1804/1804.03928.pdf.

2. Stokes, M., Anderson, M., Chandrasekar, S., Motta, R., 1996. A Standard Default Color Space for the Internet - sRGB. [online] Available at: <https://www.w3.org/Graphics/Color/sRGB.html> [Accessed 15 Apr. 2019].

3. Precise measurements are vital to colour sensor sensitivity". EET India. [online] Available at: $<$ https://www.embedded. com/design/mcus-processors-and-socs/4007122/Precise-measurements-are-the-key-to-color-sensor-sensitivity $>$ [Accessed 2 Feb. 2019].

4. Land, E.H., McCann, J.J., 1971. "Lightness and Retinex Theory". Journal of the Optical Society of America, 61(1), pp. $1-11$.

5. Lam, Hong-Kwai, Au, Oscar C., Wong, Chi-Wah, 2004. "Automatic white balancing using standard deviation of RGB components". ISCAS '04, DOI: 10.1109/ISCAS.2004.1328898.

6. Weng, Ching-Chih, Chen, Homer, Fuh, Chiou-Shann, 2005. "A Novel Automatic White Patch Method for Digital Cameras". ISCAS 2005, DOI: 10.1109/ISCAS.2005.1465458.

7. Zapryanov, G., Nikolova, I., 2012. Automatic White Balance Algorithms for Digital Still Cameras - a Comparative Study. Information Technologies and Control, 1, pp. 16-22.

Received 18.06.2019 
М.В. Іващенко, студент, факультет прикладної математики, Національний техн. ун-т України

“Київський політехнічний інститут імені Ігоря Сікорського” (НТУУ «КПІ ім. І. Сікорського»), просп. Перемоги, 37, Київ, 03056, Україна, mivaschenko_51@111.kpi.ua

Д.Д. Охримчук, студент, факультет прикладної математики, НТУУ «КПІ ім. І. Сікорського», просп. Перемоги, 37, Київ, 03056, Україна, den5096@gmail.com

Л.А. Люшенко, кандидат технічних наук, старший викладач, факультет прикладної математики, НТУУ «КПІ ім. І. Сікорського», просп. Перемоги, 37, Київ, 03056, Україна, lyushenkol@gmail.com

\section{КОНЦЕПЦІЯ ЦІЛОЧИСЛОВОЇ НОРМИ ОЦІНКИ РІЗНИЦІ МІЖ ЕЛЕМЕНТАМИ ЗОБРАЖЕННЯ 3 ВРАХУВАННЯМ БАЛАНСУ БІЛОГО}

Вступ. Оцінка різниці між двома елементами зображення є важливим блоком всіх алгоритмів графічної обробки. Проте на сьогоднішній день більшість норм, які визначаються за колірними просторами, виконують операції 3 плаваючою точкою і без врахування внутрішньої структури колірної моделі камери.

Мета. Метою даної статті є дослідження запропонованого підходу, на основі якого можливо виконати синтез цілочислової норми, що враховує баланс білого камери при розрахуванні оцінки різниці між елементами зображення.

Методи. Камера автоматично налаштовує баланс білого відповідно до одного з режимів, встановлених за замовчуванням. Оцінка різниці між двома точками зображення здійснюється за рахунок виконання нормалізації. Як метод розрахунку використовується евклідова норма.

Результати. Запропоновано підхід до нормалізації, що враховує коефіцієнти корекції балансу білого. Розрахунки виконуються з точки зору здійснення операцій з цілими значеннями, що надає можливість їх використання для безпосереднього розгортання всередині апаратної логіки пристроїв. Цей факт дозволяє знизити як загальну вартість ресурсів для виконуваних операцій, по відношенню до існуючої арифметики з плаваючою крапкою, так і зниження вимог до конфігурації датчиків.

Запропонований підхід дозволяє підвищити ефективність вимірювань при вирішенні задач комп'ютерного зору, спрямованих на порівняння точок одного зображення або при повному порівнянні відповідних елементів двох або серії зображень.

Висновки. Запропонований у статті підхід спрямований на усунення недоліків сучасних систем, що використовують оцінку кольорів. Алгоритм може використовуватися як в пристроях, які здійснюють відеозйомку, так і в комп'ютерах, які використовуються для виконання операцій обробки зображень в системах комп'ютерного зору.

Ключові слова: комп'ютерний зір, корекція балансу білого, датчики кольору, колірна модель, опорні кольори, норма точки зображення. 
M.В. Иващенко, студент, факультет прикладной математики, Национальный техн. ун-т Украины «Киевский политехнический институт имени Игоря Сикорского» (НТУУ «КПИ им. И. Сикорского»), просп. Победы, 37, Киев, 03056, Украина, mivaschenko_51@11l.kpi.ua

Д.Д. Охримчук, студент, факультет прикладной математики, НТУУ «КПИ им. И. Сикорского», просп. Победы, 37, Киев, 03056, Украина, den5096@gmail.com

Л.А. Люшенко, кандидат технических наук, старший преподаватель, кафедра программного обеспечения компьютерных систем, факультет прикладной математики (ПОКС ФПМ), НТУУ «КПИ им. И. Сикорского», просп. Победы, 37, Киев, 03056, Украина, lyushenkol@gmail.com

\section{КОНЦЕПЦИЯ ЦЕЛОЧИСЛЕННОЙ НОРМЫ ОЦЕНКИ РАЗНИЦЫ МЕЖДУ ЭЛЕМЕНТАМИ ИЗОБРАЖЕНИЯ С УЧЕТОМ БАЛАНСА БЕЛОГО}

Введение. Оценка разницы между двумя элементами изображения является важным блоком всех алгоритмов графической обработки. Однако на сегодняшний день большинство норм, которые определяются по цветовым пространствам, выполняют операции с плавающей точкой и без учета внутренней структуры цветовой модели камеры.

Цель. Целью данной статьи является исследование подхода к синтезу целочисленной нормы, которая учитывает баланс белого камеры при расчете оценки разницы между элементами изображения.

Методы. Камера автоматически настраивает баланс белого в соответствии с одним из режимов, установленных по умолчанию. Оценка разницы между двумя точками изображения осуществляется путем выполнения нормализации. В качестве метода расчета используется евклидова норма.

Результаты. Предложен подход нормализации, учитывающий коэффициенты коррекции баланса белого. Расчеты выполняются исходя из операций с целыми значениями, что дает возможность использования их для непосредственного развертывания внутри аппаратной логики устройств. Это позволяет снизить как общую стоимость ресурсов для выполняемых операций, по отношению к существующей арифметике с плавающей точкой, так и упростить требования к конфигурации датчиков.

Это повышает эффективность измерений при решении задач компьютерного зрения, направленных на сравнение точек одного изображения или при полном сравнении соответствующих элементов двух или серии изображений.

Выводы. Предложенный в статье подход направлен на устранение недостатков современных систем, использующих оценку цветов. Алгоритм может использоваться как в устройствах, видеосъемки, так и в компьютерах, используемых для выполнения операций обработки изображений в системах компьютерного зрения.

Ключевые слова: компьютерное зрение, коррекция баланса белого, датчики ивета, цветовая модель, опорные ивета, норма точки изображения. 